Volume 6, Nomor 2, Tahun 2017, Halaman 180-190

Online di : http://ejournal-s1.undip.ac.id/index.php/jnc

\title{
KONSUMSI FITOESTROGEN, PERSENTASE LEMAK TUBUH DAN SIKLUS MENSTRUASI PADA WANITA VEGETARIAN
}

\author{
Ahaddini Septian R, Nurmasari Widyastuti, Enny Probosari*) \\ *) Program Studi Ilmu Gizi Fakultas Kedokteran Universitas Diponegoro \\ Jln. Prof. H. Soedarto, SH., Semarang, Telp (024) 8453708, Email : gizifk@undip.ac.id
}

\begin{abstract}
Background: The prevalence of menstrual cycle irregularities in vegetarian was $26,5 \%$. Vegetarian diet is a diet limiting animal products and consuming phytoestrogen sources; fruits, vegetables, nuts and grains. Vegetarians have a lower body fat percentage than nonvegetarians. Phytoestrogen and body fat percentage can affect estrogen levels then disrupt menstrual cycle.

Objective : To determine the association between phytoestrogen intake and body fat percentage with menstrual cycle in vegetarian women.

Methods : Cross sectional study at 49 vegetarian woman selected by consecutive sampling. Body fat percentage was measured by Bioelectrical Impedance Analysis (BIA). Nutrients intake were obtained from Semi Quantitative Food Frequency Questionnaire (SQFFQ) and analyzed with nutrition software. Physical activity were measured by International Physical Activity Questionnaire (IPAQ). Menstrual cycle data were assessed by questionnaire. Data were analyzed by Chi Square and Binnary Logistic Regression method.

Result : The menstrual cycle distruption was found in 49,0\% vegetarian women. There were no correlation between energy intake, carbohydrate intake, fat intake, protein intake, fiber intake and physical activity with menstrual cycle $(p>0,05)$.There were correlation between phytoestrogen intake, body fat percentage and menstrual cycle distruption in the family history with menstrual cycle $(p<0,05)$. Phytoestrogen intake associated with menstrual cycle distruption which controlled by body fat percentage and menstrual cycle distruption in the family history $(p<0,05)$.

Conclusion : Phytoestrogen intake, body fat percentage and menstrual cycle distruption in the family history associated with menstrual cycle.
\end{abstract}

Keywords : Phytoestrogen intake, body fat percentage, menstrual cycle, vegetarian

\begin{abstract}
ABSTRAK
Latar Belakang : Prevalensi ketidakteraturan siklus menstruasi pada vegetarian sebesar 26,5\%. Diet vegetarian merupakan pola makan yang membatasi produk hewani dan mengonsumsi produk makanan nabati seperti buah, sayur, kacang dan biji-bijian yang merupakan sumber fitoestrogen. Vegetarian memiliki persentase lemak tubuh lebih rendah dari nonvegetarian. Fitoestrogen dan persentase lemak tubuh dapat mempengaruhi kadar estrogen dalam tubuh dan mengakibatkan gangguan siklus menstruasi.

Tujuan : Mengetahui hubungan konsumsi fitoestrogen dan persentase lemak tubuh dengan siklus menstruasi pada wanita vegetarian.

Metode : Desain penelitian cross sectional dengan 49 wanita vegetarian dipilih secara consecutive sampling. Persentase lemak tubuh diukur menggunakan Bioelectrical Impedance Analysis (BIA). Asupan zat gizi diperoleh melalui Semi Quantitative Food Frequency Questionaire (SQFFQ) dan dianalisis menggunakan program software gizi. Aktivitas fisik diukur menggunakan International Physical Activity Questionaire (IPAQ). Data siklus menstruasi diperoleh melalui kuesioner. Data dianalisis dengan uji Chi Square dan uji Regresi Logistik Ganda.

Hasil : Sebanyak 49,0\% wanita vegetarian mengalami gangguan siklus menstruasi. Tidak ada hubungan antara asupan energi, kerbohidrat, lemak, protein, serat dan aktivitas fisik dengan siklus menstruasi $(p>0,05)$. Terdapat hubungan antara konsumsi fitoestrogen, persentase lamk tubuh dan riwayat gangguan siklus menstruasi pada keluarga dengan siklus menstruasi $(p<0,05)$. Konsumsi fitoestrogen berhubungan dengan kejadian gangguan siklus menstruasi setelah dikontrol dengan persentase lemak tubuh dan riwayat gangguan menstruasi pada keluarga $(p<0,05)$.
\end{abstract}

Simpulan : Konsumsi fitoestrogen, persentase lemak tubuh dan riwayat gangguan siklus menstruasi pada keluarga berhubungan dengan siklus menstruasi.

Kata kunci : Fitoestrogen, persentase lemak tubuh, siklus menstruasi, vegetarian

\section{PENDAHULUAN}

Pola makan vegetarian telah berkembang pesat selama bertahun-tahun baik karena alasan agama maupun kesehatan. ${ }^{1}$ Hasil survey American Dietetic Association (ADA) tahun 2006 menunjukkan sekitar 4,9 juta atau 2,3\% penduduk dewasa di Amerika menjadi vegetarian dan sekitar $1,4 \%$ menjadi vegan. ${ }^{2}$ Vegetarian di Indonesia tergabung dalam suatu organisasi yang bernama Indonesia Vegetarian Society (IVS). Jumlah vegetarian yang terdaftar dalam IVS pada tahun 1998 sekitar 5.000 orang dan 
pada tahun 2007 meningkat menjadi 60.000 orang serta diperkirakan akan terus bertambah. ${ }^{3}$

Pada pelayanan kesehatan primer, sering ditemukan masalah gangguan menstruasi. Prevalensi ketidakteraturan mentruasi sebesar $26,5 \%$ pada vegetarian dan $4,9 \%$ pada nonvegetarian. ${ }^{4}$ Hasil penelitian di Iran menunjukkan kejadian gangguan siklus menstruasi paling tinggi terjadi pada wanita usia 20-25 tahun, hanya 39,8\% subjek pada penelitian tersebut yang mengalami siklus menstruasi normal. ${ }^{5}$ Siklus menstruasi pendek atau panjang menunjukkan adanya penyimpangan pada sistem metabolisme dan hormonal. Dampaknya yaitu menjadi lebih sulit hamil (infertilitas). Wanita yang mengalami siklus menstruasi pendek dapat berisiko unovulasi karena sel telur tidak selalu matang sehingga sulit untuk dibuahi. Siklus menstruasi panjang pada wanita menandakan sel telur jarang sekali diproduksi atau wanita mengalami ketidaksuburan yang cukup panjang. ${ }^{6}$

Siklus menstruasi dipengaruhi oleh beberapa faktor, yaitu gangguan hormonal, pertumbuhan organ reproduksi, status gizi, stres, usia menarche dan aktivitas fisik. ${ }^{7,8}$ Estrogen berperan penting pada siklus menstruasi. Konsumsi fitoestrogen mempengaruhi kadar estrogen dalam tubuh. Fitoestrogen merupakan senyawa yang ditemukan pada makanan nabati seperti kacang kedelai, tahu, tempe, buah-buahan, dan sayur-sayuran yang bersifat mirip dengan estrogen pada wanita. ${ }^{9}, 10$ Berdasarkan penelitian meta analisis, asupan fitoestrogen dapat meningkatkan panjang siklus menstruasi, menekan tingkat Luteizing Hormone (LH) dan FollicleStimulating Hormone (FSH) serta menurunkan konstentrasi kolesterol pada fase folikuler. ${ }^{11,12}$ Wanita vegetarian biasanya mengonsumsi makanan sumber fitoestrogen lebih banyak daripada wanita nonvegetarian. ${ }^{9}$ Berdasarkan penelitian pada 6 wanita nonvegetarian di Texas, terdapat perubahan siklus menstruasi dari rata-rata 28,3 hari meningkat menjadi 31,8 hari setelah 1 bulan intervensi susu kedelai. ${ }^{13}$

Keadaan yang menghambat kadar estrogen akan memengaruhi siklus menstruasi yang normal. ${ }^{14}$ Diet rendah lemak dan tinggi serat dapat mengurangi kadar estrogen dalam tubuh. Presentase lemak tubuh menggambarkan massa lemak dalam tubuh. Vegetarian memiliki Indeks Massa Tubuh (IMT) dan persentase lemak tubuh yang lebih rendah daripada nonvegetarian. ${ }^{15}$ Berdasarkan penelitian di Manado menunjukkan dari 67 responden, hanya $9(33,3 \%)$ responden dengan status gizi kurus dan $2(18,2 \%)$ responden dengan status gizi gemuk memiliki siklus menstruasi teratur, serta $6(20,7 \%)$ responden dengan status gizi normal mengalami siklus menstruasi tidak teratur. ${ }^{16}$ Lemak tubuh berperan dalam memengaruhi tingkat sekresi dan keseimbangan hormon reproduksi yang mengatur menstruasi dalam tubuh. Wanita yang memiliki lemak tubuh kurang atau lebih akan mengalami perubahan kadar hormon steroid yang dapat menimbulkan gangguan siklus menstruasi. ${ }^{17}$

Di Indonesia belum banyak penelitian mengenai siklus menstruasi pada vegetarian, sehingga peneliti tertarik untuk meneliti konsumsi fitoestrogen, persentase lemak tubuh dan siklus menstruasi pada wanita vegetarian.

\section{METODE}

Penelitian ini merupakan penelitian deskriptif analitik dengan metode cross sectional, termasuk dalam ruang lingkup ilmu gizi masyarakat, dan dilakukan di IVS cabang Yogyakarta pada Desember 2016. Populasi dalam penelitian ini adalah semua wanita vegetarian yang tergabung dalam IVS cabang Yogyakarta. Kriteria inklusi sampel penelitian ini yaitu bersedia mengisi informed consent, berusia 1925 tahun, sudah menjalani pola hidup vegetarian minimal 6 bulan, sudah mengalami menstruasi, tidak dalam kondisi sakit, tidak merokok, tidak mengonsumsi alkohol, tidak mengonsumsi obatobatan seperti nerothinodrel dan pil KB, dan dapat berkomunikasi dengan baik. Berdasarkan perhitungan sampel menggunakan rumus analitik korelatif dibutuhkan sampel minimal 44 orang. Pemilihan sampel menggunakan teknik consecutive sampling dan didapatkan 49 orang yang sesuai dengan kriteria inklusi.

Variabel bebas dalam penelitian ini yaitu konsumsi fitoestrogen dan persentase lemak tubuh. Variabel perancu dalam penelitian ini yaitu asupan zat gizi (energi, karbohidrat, protein, lemak dan serat) aktivitas fisik dan riwayat gangguan siklus menstruasi pada keluarga. Variabel terikatnya adalah siklus menstruasi. Data yang diambil dalam penelitian ini antara lain data identitas sampel, data antropometri (tinggi badan, berat badan dan persentase lemak tubuh), data asupan zat gizi (asupan fitoestrogen, energi, karbohidrat, protein, lemak dan serat), data aktivitas fisik, riwayat gangguan menstruasi pada keluarga, serta data siklus menstruasi. Pengambilan sampel diawali dengan melakukan pengumpulan data meliputi identitas sampel, pengukuran tinggi badan menggunakan microtoise dengan ketelitian $0,1 \mathrm{~cm}$, dan pengukuran berat badan dengan menggunakan timbangan injak digital dengan ketelitian $0,1 \mathrm{~kg}$.

Persentase lemak tubuh didefinisikan sebagai perbandingan total lemak dengan berat badan yang diukur menggunakan Bioelectrical Impedance Analysis (BIA) dengan ketelitian 0,1\%. Hasil ukur dinyatakan dalam bentuk persentase (\%) dan dikategorikan menjadi underfat $(<21 \%)$, normal (21$32 \%)$, overfat (33-39\%) dan obesitas (>39\%). ${ }^{18}$ 
Asupan fitoestrogen, energi, karbohidrat, protein, lemak dan serat didefinisikan sebagai jumlah asupan yang berasal dari makanan dan minuman yang dikonsumsi sehari-hari diperoleh melalui wawancara langsung menggunakan Semi Quantitative Food Frequency Questionare (SQFFQ) oleh enumerator terlatih. Data yang diperoleh dianalisis menggunakan software gizi kemudian dibandingkan dengan Angka Kecukupan Gizi (AKG) dan dikategorikan menjadi tiga yaitu kurang $(<80 \%)$, cukup $(80-110 \%)$ dan lebih $(>110 \%) .{ }^{19}$ Asupan fitoestrogen dikategorikan menjadi tiga yaitu kurang ( $<30 \mathrm{mg} /$ hari), cukup (30$50 \mathrm{mg} /$ hari) dan lebih (>50 mg/hari).$^{20}$ Asupan serat dikategorikan menjadi tiga yaitu kurang $(<20 \mathrm{~g} / \mathrm{hari})$, cukup (20-30 g/hari) dan lebih (>30 g/hari). ${ }^{21}$

Aktivitas fisik diukur menggunakan International Physical Activity Questionaire (IPAQ) untuk mengetahui besar energi yang dikeluarkan subjek dalam berkegiatan selama 7 hari terakhir kemudian dilakukan skoring dan dihitung menggunakan rumus yang sudah ditentukan dengan satuan MET-menit/minggu. Hasil perhitungan dikategorikan menjadi aktivitas ringan (<600 METmenit/minggu), aktivitas sedang (600-2999 METmenit/minggu) dan aktivitas berat (>2999 METmenit/minggu). ${ }^{22}$

Riwayat gangguan siklus menstruasi pada keluarga didefinisikan adanya anggota keluarga inti yang mengalami gangguan siklus menstruasi kemudian dikategorikan menjadi iya atau tidak. ${ }^{23}$

Gangguan siklus menstruasi didefinisikan sebagai gangguan siklus menstruasi yang dialami 3 bulan terakhir, ditandai dengan panjang jarak antara hari pertama siklus menstruasi dengan hari pertama siklus menstruasi berikutnya $<21$ hari atau $>35$ hari. Data kejadian gangguan siklus menstruasi diperoleh dengan recall menggunakan kuesioner. Hasil recall dikategorikan menjadi 4 yaitu polimenorea (siklus menstruasi <21 hari), normal ( siklus menstruasi 2135 hari), oligomenorea (siklus menstruasi $>35$ hari) dan amenorea (siklus $>3$ bulan). ${ }^{24,25}$

Analisis univariat dilakukan untuk mendeskripsikan masing-masing variabel. Analisis bivariat menggunakan uji Chi Square digunakan untuk mengetahui hubungan masing-masing variabel bebas dengan siklus menstruasi yaitu dengan mengategorikan setiap variabel bebas dan perancu menjadi dua kategori, yaitu berisiko gangguan siklus menstruasi (persentase lemak tubuh underfat atau overfat, asupan kurang atau lebih, aktivitas fisik ringan atau berat, serta terdapat riwayat gangguan siklus menstruasi pada keluarga) dan tidak berisiko gangguan siklus menstruasi (persentase lemak tubuh normal, asupan cukup, aktivitas fisik sedang dan tidak terdapat riwayat gangguan menstruasi pada keluarga). Analisis multivariat menggunakan uji regresi logistik ganda dilakukan untuk melihat variabel yang paling berhubungan.

\section{HASIL PENELITIAN \\ Karakteristik Subjek}

Sebanyak 49 subjek terdiri dari 4 orang lacto vegetarian, 27 orang lacto ovo vegetarian dan 18 orang vegan. Berdasarkan tabel 1 , rerata indeks massa tubuh (IMT) dan persentase lemak tubuh subjek tergolong normal, yaitu $19,8137 \pm 2,07426 \%$ dan $23,40 \pm 4,282 \%$. Subjek memiliki rentang usia menarche yang normal yaitu 11 sampai 14 tahun dengan sebagian besar subjek mengalami menarche pada usia 11 tahun. Rerata asupan fitoestrogen dan protein tergolong cukup, namun rerata asupan energi, karbohidrat, lemak dan serat tergolong kurang. Aktivitas fisik subjek tergolong ringan dengan rerata 494,72 \pm 463,342 MET-menit/minggu.

Tabel 1. Nilai Minimum, Maksimum, Rerata dan Standar Deviasi Karakteristik Subjek.

\begin{tabular}{lrrr}
\hline \multirow{2}{*}{ Karakteristik Subjek } & \multicolumn{3}{c}{$\mathbf{n = 4 9}$} \\
\cline { 2 - 4 } & Minimum & Maksimum & Rerata \pm SD \\
\hline Usia responden (tahun) & 19 & 25 & $21,39 \pm 2,060$ \\
Lama vegetarian (tahun) & 0,5 & 25 & $7,90 \pm 9,232$ \\
Usia menarche (tahun) & 11 & 14 & $11,86 \pm 0,756$ \\
Berat badan (kg) & 40,0 & 72,4 & $48,57 \pm 6,728$ \\
Tinggi badan (cm) & 144,0 & 169,5 & $156,39 \pm 4,965$ \\
Indeks Massa Tubuh (kg/m ${ }^{2}$ ) & 16,95 & 26,00 & $19,8137 \pm 2,07426$ \\
Persentase lemak tubuh (\%) & 18,6 & 36,8 & $23,40 \pm 4,282$ \\
Asupan & & & \\
Asupan fitoestrogen (mg) & 10,28 & 85,0 & $49,16 \pm 18,053$ \\
Asupan energi (kkal) & 733,1 & 2385,7 & $1579,4 \pm 404,375$ \\
Asupan karbohidrat (g) & 108,5 & 332,7 & $229,2 \pm 60,031$ \\
Asupan lemak (g) & 15,8 & 82,5 & $49,58 \pm 16,735$ \\
Asupan protein (g) & 19,2 & 60,80 & $51,23 \pm 9,497$ \\
Asupan serat (g) & 3,7 & 41,0 & $18,96 \pm 7,999$ \\
Aktifitas fisik (MET-menit/minggu) & 99,0 & 2415,0 & $494,72 \pm 463,324$ \\
\hline
\end{tabular}




\section{Persentase Lemak Tubuh}

Persentase lemak tubuh subjek penelitian ini sebagian besar tergolong normal yaitu sebanyak 29 subjek $(59,2 \%)$ walaupun terdapat 19 subjek $(38,8 \%)$ tergolong underfat dan 1 subjek (2\%) yang tergolong overfat (tabel 2).

\section{Asupan Zat Gizi}

Sebanyak 44,9\% subjek memiliki asupan fitoestrogen tergolong cukup dan lebih, sedangkan asupan energi $(67,3 \%)$, asupan karbohidrat $(61,2 \%)$, asupan lemak $(75,5 \%)$, dan asupan serat $(51,0 \%)$ tergolong kurang. Sebanyak 39 (79,6\%) subjek memiliki asupan protein tergolong cukup (Tabel 3).

Tabel 2. Distribusi Frekuensi Persentase Lemak Tubuh.

\begin{tabular}{lrrr}
\hline & Kategori & \multicolumn{3}{c}{ Frekuensi } \\
\cline { 2 - 4 } & (n) & $\mathbf{( \% )}$ \\
\hline Underfat & 19 & 38,8 \\
Normal & 29 & 59,2 \\
Overfat & 1 & 2,0 \\
\hline
\end{tabular}

Tabel 3. Distribusi Frekuensi Asupan Zat Gizi.

\begin{tabular}{lrr}
\hline \multicolumn{1}{c}{ Kategori } & Frekuensi & \\
\cline { 2 - 3 } & $(\mathbf{n})$ & $\mathbf{( \% )}$ \\
\hline Asupan Fitoestrogen & 5 & 10,2 \\
Kurang & 22 & 44,9 \\
Cukup & 22 & 44,9 \\
Lebih & & \\
Asupan Energi & 33 & 67,3 \\
Kurang & 16 & 32,7 \\
Cukup & 0 & 0 \\
Lebih & & \\
Asupan Karbohidrat & 30 & 61,2 \\
Kurang & 19 & 38,8 \\
Cukup & 0 & 0 \\
Lebih & & 75,5 \\
Asupan Lemak & 37 & 24,5 \\
Kurang & 12 & 0 \\
Cukup & 0 & 20,4 \\
Lebih & & 79,6 \\
Asupan Protein & 10 & 0 \\
Kurang & 16 & \\
Cukup & 39 & 51,0 \\
Lebih & 0 & 44,9 \\
Ksupan Serat & & \\
Cukup & 25 & \\
Lebih & 22 & 2 \\
\hline
\end{tabular}

\section{Aktivitas Fisik}

Aktivitas fisik 36 subjek (73,5\%) tergolong ringan, 13 subjek $(26,5 \%)$ memiliki aktivitas fisik sedang, dan tidak ada subjek dengan aktivitas fisik berat.

\section{Riwayat Gangguan Siklus Menstruasi pada Keluarga}

Sebanyak 12 subjek $(24,5 \%)$ memiliki riwayat gangguan menstruasi pada keluarga dan 37 subjek $(75,5 \%)$ lainnya tidak.

\section{Gangguan Siklus Menstruasi}

Sebanyak $49 \%$ subjek mengalami gangguan siklus menstruasi. Berdasarkan tabel 4, dapat dilihat gangguan siklus menstruasi yang dialami beragam.

Tabel 6 menunjukkan bahwa sebagian besar subjek underfat memiliki asupan fitoestrogen yang tinggi, hal ini dimungkinkan menjadi penyebab terjadinya gangguan siklus menstruasi. 
Tabel 4. Kejadian Gangguan Siklus Menstruasi Selama 3 Bulan Terakhir.

\begin{tabular}{llrrr}
\hline \multicolumn{1}{c}{ Karakteristik } & \multicolumn{2}{c}{ Kategori } & \multicolumn{2}{c}{ Frekuensi } \\
\cline { 3 - 5 } & & (n) & $(\%)$ \\
\hline Kejadian & Normal & & 25 & 51,0 \\
gangguan siklus & Gangguan siklus & 24 & 49,0 \\
menstruasi & menstruasi & Oligomenorea & 20 & 40,8 \\
& & Oligomenorea & 2 & 4,1 \\
& & dan amenorea & & 4,1 \\
\hline
\end{tabular}

Tabel 5. Distribusi Frekuensi Kejadian Gangguan Siklus Menstruasi.

\begin{tabular}{|c|c|c|c|}
\hline \multirow[t]{3}{*}{ Karakteristik dan Kategori } & \multicolumn{2}{|c|}{$\begin{array}{c}\text { Kejadian Gangguan Siklus } \\
\text { Menstruasi }\end{array}$} & \multirow[t]{2}{*}{ Total } \\
\hline & Gangguan & Normal & \\
\hline & $n(\%)$ & $\mathrm{n}(\%)$ & n (\%) \\
\hline \multicolumn{4}{|l|}{ Persentase Lemak tubuh } \\
\hline Underfat & $16(82,4 \%)$ & $3(15,8 \%)$ & $19(10 \%)$ \\
\hline Normal & $7(24,1 \%)$ & $22(75,9 \%)$ & $29(100 \%)$ \\
\hline Overfat & $1(100 \%)$ & $0(0 \%)$ & $1(100 \%)$ \\
\hline \multicolumn{4}{|l|}{ Asupan Fitoestrogen } \\
\hline Kurang & $4(80 \%)$ & $1(20 \%)$ & $5(100 \%)$ \\
\hline Cukup & $1(4,5 \%)$ & $21(95,5 \%)$ & $22(100 \%)$ \\
\hline Lebih & $19(86,4 \%)$ & $3(13,6 \%)$ & $22(100 \%)$ \\
\hline \multicolumn{4}{|l|}{ Asupan Energi } \\
\hline Kurang & $17(51,5 \%)$ & $16(48,5 \%)$ & $33(100 \%)$ \\
\hline Cukup & $7(43,8 \%)$ & $9(56,2 \%)$ & $16(100 \%)$ \\
\hline Lebih & $0(0 \%)$ & $0(0 \%)$ & $0(0 \%)$ \\
\hline \multicolumn{4}{|l|}{ Asupan Karbohidrat } \\
\hline Kurang & $15(50 \%)$ & $15(50 \%)$ & $30(100 \%)$ \\
\hline Cukup & $9(47,4 \%)$ & $10(52,6 \%)$ & $19(100 \%)$ \\
\hline Lebih & $0(0 \%)$ & $0(0 \%)$ & $0(0 \%)$ \\
\hline \multicolumn{4}{|l|}{ Asupan Lemak } \\
\hline Kurang & $18(48,6 \%)$ & $19(51,4 \%)$ & $37(100 \%)$ \\
\hline Cukup & $6(50 \%)$ & $6(50 \%)$ & $12(100 \%)$ \\
\hline Lebih & $0(0 \%)$ & $0(0 \%)$ & $0(0 \%)$ \\
\hline \multicolumn{4}{|l|}{ Asupan Protein } \\
\hline Kurang & $3(30 \%)$ & $7(70 \%)$ & $10(100 \%)$ \\
\hline Cukup & $21(53,8 \%)$ & $18(46,2 \%)$ & $39(100 \%)$ \\
\hline Lebih & $0(0 \%)$ & $0(0 \%)$ & $0(0 \%)$ \\
\hline \multicolumn{4}{|l|}{ Asupan Serat } \\
\hline Kurang & $11(44 \%)$ & $14(56 \%)$ & $25(100 \%)$ \\
\hline Cukup & $12(54,5 \%)$ & $10(45,5 \%)$ & $22(100 \%)$ \\
\hline Lebih & $1(50 \%)$ & $1(50 \%)$ & $2(100 \%)$ \\
\hline \multicolumn{4}{|l|}{ Aktivitas Fisik } \\
\hline Ringan & $17(47,2 \%)$ & $19(52,8 \%)$ & $36(100 \%)$ \\
\hline Sedang & $7(53,8 \%)$ & $6(46,2 \%)$ & $13(100 \%)$ \\
\hline \multicolumn{4}{|l|}{ Riwayat Keluarga } \\
\hline Iya & $11(91,7 \%)$ & $1(8,3 \%)$ & $12(100 \%)$ \\
\hline Tidak & $13(35,1 \%)$ & $24(64,9 \%)$ & $37(100 \%)$ \\
\hline \multicolumn{4}{|l|}{ Tipe Vegetarian } \\
\hline Lacto vegetarian & $2(50 \%)$ & $2(50 \%)$ & $4(100 \%)$ \\
\hline Lacto-ovo vegetarian & $10(37 \%)$ & $17(63 \%)$ & $27(100 \%)$ \\
\hline Vegan & $12(66,7 \%)$ & $6(33,3 \%)$ & $18(100 \%)$ \\
\hline
\end{tabular}


Tabel 6. Distribusi Persentase Lemak Tubuh dan Asupan Fitoestrogen

\begin{tabular}{crrrr}
\hline Persentase & \multicolumn{2}{c}{ Konsumsi Fitoestrogen } & & \multicolumn{2}{c}{$\begin{array}{c}\text { Total } \\
\text { Lemak }\end{array}$} & \multicolumn{1}{c}{ Kurang } & \multicolumn{1}{c}{ Cukup } & \multicolumn{1}{c}{ Lebih } & n & \\
\cline { 2 - 4 } Tubuh & $\mathbf{n}(\%)$ & \multicolumn{1}{c}{ n (\%) } & \multicolumn{1}{c}{ n (\%) } & \\
\hline Underfat & $2(10,5 \%)$ & $2(10,5 \%)$ & $15(79,0 \%)$ & $19(100 \%)$ \\
Normal & $2(6,9 \%)$ & $20(69,0 \%)$ & $7(24,1 \%)$ & $29(100 \%)$ \\
Overfat & $1(100 \%)$ & $0(0 \%)$ & $0(0 \%)$ & $1(100 \%)$ \\
\hline
\end{tabular}

Persentase Lemak Tubuh, Asupan Fitoestrogen, menstruasi $(p<0,05)$ tetapi tidak ada hubungan antara Energi, Karbohidrat, Lemak, Protein, Serat, asupan energi, karbohidrat, lemak, protein, serat, dan Aktivitas Fisik, dan Riwayat Gangguan Silus aktivitas fisik dengan gangguan siklus menstruasi Menstruasi pada Keluarga dengan Gangguan $(p>0,05)$. Setelah dilakukan analisis multivariat pada Siklus Menstruasi

Hasil analisis statistik pada tabel 7 menunjukkan adanya hubungan antara persentase lemak tubuh, asupan fitoestrogen dan riwayat gangguan siklus menstruasi pada keluarga dengan gangguan siklus

ketiga variabel tersebut, hanya konsumsi fitoestrogen yang berhubungan pada kejadian gangguan siklus menstruasi $(p<0,05)$ dengan besar pengaruh konsumsi fitoestrogen sebesar 4,020 (Tabel 8).

Tabel 7. Analisis Bivariat Hubungan Persentase Lemak Tubuh, Asupan Fitoestrogen, Energi, Karbohidrat, Lemak, Protein, Aktivitas Fisik, dan Riwayat Gangguan Menstruasi pada Keluarga dengan Siklus Menstruasi.

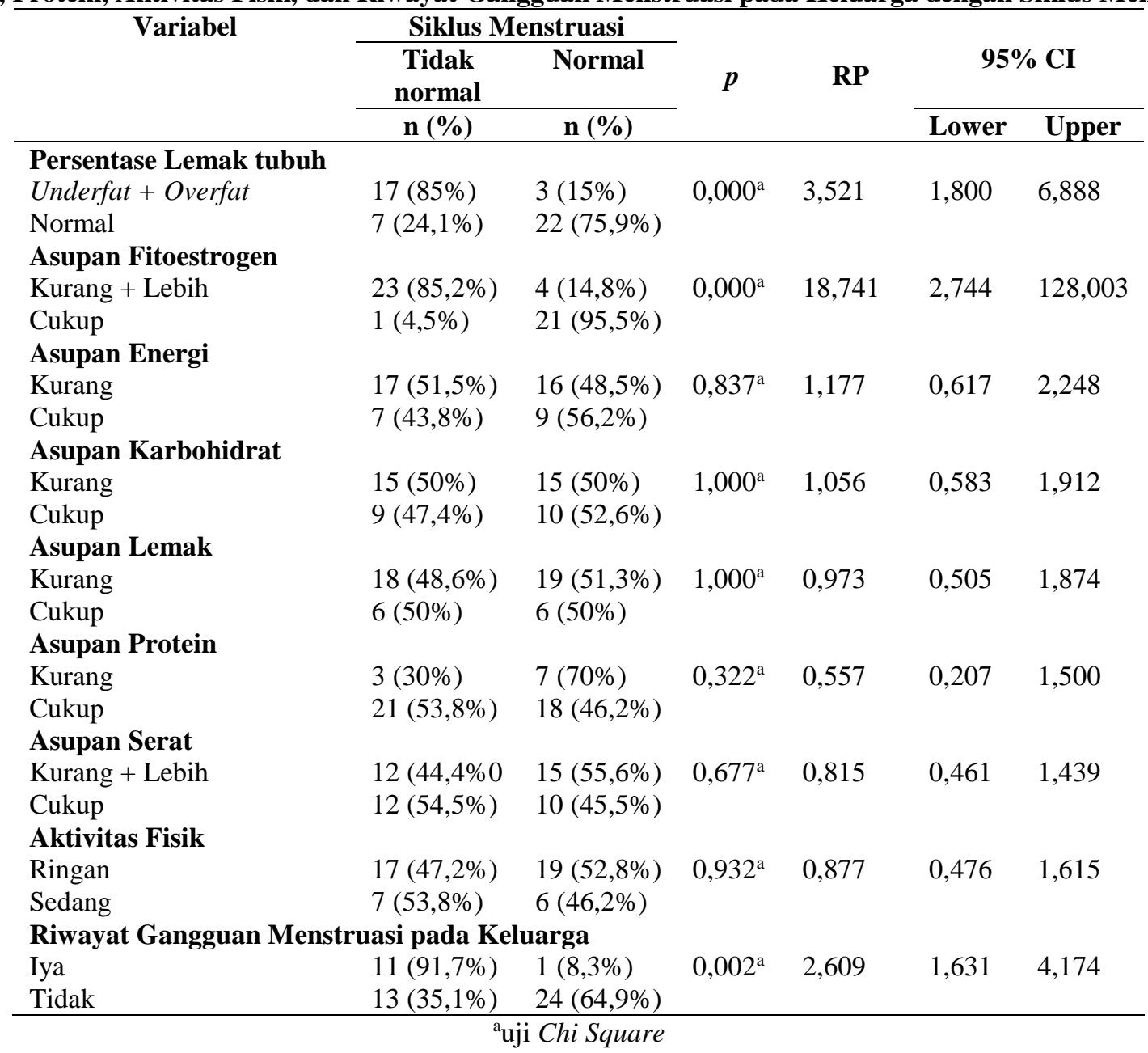

Tabel 8. Analisis Multivariat Variabel yang Memengaruhi Siklus Menstruasi.

\begin{tabular}{lcccc}
\hline \multicolumn{1}{c}{ Variabel } & Koefisien & $\boldsymbol{p}$ & OR & 95\% CI \\
\hline Persentase Lemak Tubuh & 1,476 & $0,179^{\mathrm{b}}$ & 4,374 & $0,508 \pm 37,671$ \\
Asupan Fitoestrogen & 4,020 & $0,001^{\mathrm{b}}$ & 55,688 & $4,943 \pm 627,420$ \\
Riwayat Ganguan Menstruasi pada & 2,336 & $0,167^{\mathrm{b}}$ & 10,339 & $0,376 \pm 284,037$
\end{tabular}


Tabel 9. Perbedaan Rerata Persentase Lemak Tubuh, Asupan Fitoestrogen, Energi, Karbohidrat, Lemak, Protein, Serat dan Aktivitas Fisik pada Kedua Kelompok.

\begin{tabular}{lrr}
\hline \multicolumn{1}{c}{ Kategori } & $\begin{array}{c}\text { Kelompok Subjek } \\
\text { dengan Siklus } \\
\text { Menstruasi Normal }\end{array}$ & $\begin{array}{c}\text { Kelompok Subjek } \\
\text { dengan Gangguan Siklus } \\
\text { Menstruasi }\end{array}$ \\
\hline Persentase lemak tubuh (\%) & $24,30 \pm 3,6$ & $22,46 \pm 4,8$ \\
Asupan & & \\
Asupan fitoestrogen (mg) & $41,9 \pm 11,3$ & $56,7 \pm 20,7$ \\
Asupan energi (kkal) & $1602,2 \pm 434,8$ & $1555,5 \pm 378,4$ \\
Asupan karbohidrat (g) & $234,0 \pm 61,9$ & $224,1 \pm 58,8$ \\
Asupan lemak (g) & $50,3 \pm 17,9$ & $48,8 \pm 15,7$ \\
Asupan protein (g) & $50,24 \pm 11,5$ & $52,2 \pm 6,9$ \\
Asupan serat (g) & $17,54 \pm 8,3$ & $20,4 \pm 7,6$ \\
Aktifitas fisik (MET-menit/minggu) & $353,5 \pm 411,0$ & $536,6 \pm 517,8$ \\
\hline
\end{tabular}

\section{PEMBAHASAN}

\section{Karakteristik Subjek}

Penelitian ini dilakukan pada subjek wanita dewasa muda vegetarian dengan rentang usia 19-25 tahun yang merupakan bagian dari rentang usia dewasa yaitu 19-40 tahun. Pada tahap dewasa muda terjadi proses pematangan pertumbuhan dan perkembangan fisik maupun psikologis. Pematangan pertumbuhan dan perkembangan fisik meliputi berbagai organ, salah satunya organ reproduksi. Kesehatan reproduksi pada tahap ini sangat penting karena berkaitan erat dengan tingkat fertilitas. ${ }^{5}$ Hasil penelitian ini menunjukkan bahwa dari 49 subjek sebanyak 24 subjek (49\%) mengalami gangguan siklus menstruasi. Hasil penelitian ini sejalan dengan penelitian di Iran, bahwa kejadian gangguan siklus menstruasi pada usia reproduktif paling tinggi terjadi pada wanita berusia 20-25 tahun dan hanya 39,8\% subjek yang memiliki siklus menstruasi normal. ${ }^{5}$ Sebanyak $66,7 \%$ yang mengalami gangguan siklus menstruasi merupakan vegan.

\section{Persentase Lemak Tubuh dan Siklus Menstruasi}

Pada wanita yang memiliki persentase lemak tubuh rendah terjadi penurunan produksi androstenedion yang merupakan hormon androgen yang berfungsi sebagai prekursor hormon reproduksi. Androgen digunakan untuk memproduksi estrogen di dalam tubuh dengan bantuan enzim aromatase. Proses aromatisasi androgen menjadi estrogen ini terjadi di sel-sel granulosa dan jaringan lemak. Semakin rendah persentase lemak tubuh, semakin sedikit pula estrogen yang terbentuk yang kemudian dapat mengganggu keseimbangan hormon di dalam tubuh sehingga menyebabkan terjadinya gangguan siklus menstruasi. ${ }^{7}$

Secara fisiologis terdapat tiga jenis hormon yang memiliki efek estrogenik yaitu beta estradiol, estron, dan esteriol. Diantara ketiga hormon tersebut, beta estradiol ditemukan dalam jumlah bermakna dalam plasma wanita sehingga diyakini sebagai estrogen utama pada wanita. Sintesis estradiol dalam tubuh konsisten sesuai dengan kebutuhan selama dukungan penyuplainya cukup yaitu kolesterol plasma dan asetil koenzim A. Meningkatnya asupan makanan yang menyebabkan kolesterol turun akan mengakibatkan kolesterol plasma menurun, kondisi ini dapat menurunkan sintesis estradiol dan total estradiol plasma. ${ }^{26}$

Lemak tubuh berperan penting pada tingkat sekresi dan keseimbangan hormon reproduksi pengatur menstruasi karena lemak berperan dalam membentuk, mengonversi dan menyimpan hormonhormon reproduksi. Rendahnya persentase lemak tubuh dapat mengakibatkan rendahnya kadar estrogen yang berhubungan dengan kejadian infertilitas. Peningkatan lemak tubuh akan meningkatkan jumlah estrogen dalam darah sehingga mengakibatkan siklus menstruasi menjadi lebih panjang dan mengakibatkan hiperplasi pembuluh darah. Hiperplasi pembuluh darah yaitu terdesaknya pembuluh darah oleh jaringan lemak yang jika terjadi pada organ reproduksi wanita akan mengakibatkan menstruasi lebih lama dan siklus menstruasi yang tidak teratur. ${ }^{7}$

Sebanyak $19 \quad(38,8 \%)$ subjek memiliki persentase lemak tubuh underfat yang kemungkinan disebabkan oleh asupan lemak yang kurang dan hanya satu $(2,0 \%)$ subjek overfat sehingga dikategorikan berisiko mengalami gangguan siklus menstruasi. Hasil analisis bivariat menunjukkan adanya hubungan antara persentase lemak tubuh dengan gangguan siklus menstruasi $(p<0,05 ; \mathrm{RP}=3,521 ; 95 \% \mathrm{CI}=1,800-6,888) . \quad$ Subjek dengan persentase lemak tubuh underfat atau overfat memiliki risiko kejadian gangguan siklus menstruasi 3,521 kali lebih besar daripada subjek dengan lemak tubuh normal. Hasil penelitian ini sejalan dengan penelitian yang menemukan tingginya insiden amenore primer, amenore sekunder, siklus menstruasi tidak teratur dan tertundanya menarche berhubungan dengan tingkat kerampingan tubuh. Peneliti lain juga menemukan adanya gangguan menstruasi oligomenore pada remaja dengan persentase lemak tubuh rendah. ${ }^{27}$ Lemak tubuh berhubungan dengan siklus menstruasi, persentase 
lemak tubuh yang tinggi mengakibatkan siklus menstruasinya tidak normal. ${ }^{7}$

\section{Konsumsi Fitoestrogen dan Siklus Menstruasi}

Sebanyak 23 subjek $(85,2 \%)$ yang memiliki asupan fitoestrogen kurang atau lebih mengalami gangguan siklus menstruasi. Hasil analisis statistik menyebutkan adanya hubungan antara konsumsi fitoestrogen dengan gangguan siklus menstruasi ( $p<0,05 ; \mathrm{RP}=18,741 ; 95 \% \mathrm{CI}=2,744-128,003)$. Subjek yang memiliki asupan fitoestrogen kurang atau lebih memiliki risiko 18,741 kali lebih besar mengalami gangguan siklus menstruasi dibandingkan subjek yang memiliki asupan fitoestrogen cukup.

Fitoestrogen adalah estrogen lemah yang terdapat pada tanaman. Istilah fitoestrogen berhubungan dengan beberapa kelas senyawa kimia seperti flavones, flavanones, isoflavones, coumestans dan lignans. Senyawa-senyawa tersebut memiliki struktur yang mirip dengan estrogen endogen, tetapi memberikan efek campuran antara efek estrogenik dan efek anti-estrogenik. ${ }^{9}$

Hasil penelitian ini sejalan dengan penelitian ekeperimental selama 9 bulan dimana subjek yang diberikan Texturized Vegetable Protein (TVP) 60 $\mathrm{g} /$ hari (45 mg isoflavon) rerata panjang siklus menstruasi meningkat dari 27 hari menjadi 29 hari. Subjek yang diberikan Miso $50 \mathrm{~g} / \mathrm{hari}(25 \mathrm{mg}$ isoflavon) rata-rata panjang siklus menstruasi meningkat dari 25 hari menjadi 30 hari. Subjek yang diberikan TVP $28 \mathrm{~g} /$ hari (23 mg isoflavon) terjadi perubahan rata-rata panjang siklus menstruasi dari 33 hari menjadi 32 hari. Pada penelitian di Texas, terdapat perubahan siklus menstruasi dari rata-rata 28,3 hari meningkat menjadi 31,8 hari setelah 1 bulan intervensi susu kedelai. ${ }^{28}$

Fitoestrogen mempunyai afinitas terhadap reseptor estrogen 1.000-10.000 kali lebih kecil daripada estradiol. Fitoestrogen dapat menstimulasi sintesis sex-hormone binding globulin di dalam liver dan menimbulkan inhibisi kompetitif terhadap ikatan antara estrogen dan reseptornya yang mengakibatkan berkurangnya kadar hormon aktif dalam sirkulasi darah. Fitoestrogen dapat menghambat aktivitas enzim pengendali steroidogenesis (enzim aromatase) sehingga menghambat sintesis estradiol dari androgen dan estrogen sulfat. Fitoestrogen diekskresikan melalui urin, dimana diet vegetarian berhubungan dengan tingginya kadar lignan dalam urin. ${ }^{9}$

Asupan Energi, Karbohidrat, Protein, Lemak, Serat dan Siklus Menstruasi

Sebanyak $67,3 \%$ subjek memiliki asupan energi kurang, hal ini disebabkan oleh porsi makan yang sedikit dan sering meninggalkan sarapan. Kekurangan atau kelebihan asupan energi mengakibatkan perubahan kadar hormon estrogen sebagai pengatur siklus menstruasi sehingga dapat menurunkan fungsi reproduksi dan gangguan siklus menstruasi. $^{29}$

Subjek dengan asupan energi kurang memiliki risiko 1,177 kali lebih besar untuk mengalami gangguan siklus menstruasi, meskipun secara statistik tidak ada hubungan antara asupan energi dengan siklus menstruasi $(p=0,837 ; \mathrm{RP}=1,177$; $95 \% \mathrm{CI}=0,617-2,248)$. Rerata asupan energi subjek yang mengalami gangguan siklus menstruasi sebesar $1555,5 \pm 378,4$ kkal dan pada subjek yang siklus menstruasinya normal sebesar 1602,2 $\pm 434,8 \mathrm{kkal}$, perbedaan rerata asupan energi pada dua kelompok subjek dapat menyebabkan perbedaan kadar estrogen. Hasil penelitian ini tidak sejalan dengan penelitian yang menyebutkan bahwa terdapat hubungan asupan energi dengan siklus menstruasi dimana subjek dengan asupan energi defisit tingkat berat dan sedang memiliki risiko 7,14 kali lebih besar mengalami gangguan siklus menstruasi dibandingkan subjek dengan asupan energi defisit tingkat ringan dan normal. ${ }^{18}$

Sebanyak $61,2 \%$ subjek memiliki asupan karbohidrat kurang. Karbohidrat merupakan sumber kalori selama fase luteal, apabila asupan karbohidrat terpenuhi maka tidak akan terjadi pemendekan fase luteal. ${ }^{4,30}$ Karbohidrat berperan penting dalam pengaturan glukosa darah. Konsentrasi glukosa darah yang rendah dapat mengakibatkan tubuh memproduksi hormon adrenalin. Adrenalin dapat menghentikan efektivitas progesteron yang berfungsi menekan aktivitas kerja hormon estrogen. ${ }^{31}$

Subjek dengan asupan karbohidrat kurang memiliki risiko 1,056 kali lebih besar megalami gangguan siklus menstruasi, meskipun secara statistik tidak ada hubungan asupan karbohidrat dengan siklus menstruasi ( $p>0,05 ; \mathrm{RP}=1,056 ; 95 \% \mathrm{CI}=0,583-1,912)$. Rerata asupan karbohidrat pada kelompok subjek dengan gangguan siklus menstruasi tergolong kurang yaitu $224,1 \pm 58,8$ gram dan $234,0 \pm 61,9$ gram pada subjek dengan siklus menstruasi normal. Hasil penelitian ini tidak sejalan dengan penelitian yang menyatakan bahwa ada hubungan asupan karbohidrat dengan siklus menstruasi dimana subjek dengan asupan karbohidrat defisit tingkat berat dan sedang memiliki risiko 4,15 kali lebih besar mengalami gangguan siklus menstruasi dibandingkan subjek dengan asupan energi defisit tingkat ringan dan normal. ${ }^{18} \mathrm{Hal}$ ini dimungkinkan karena jumlah subjek dengan asupan karbohidrat kurang yang mengalami gangguan siklus menstruasi ataupun tidak berjumlah sama yaitu 15 (50\%) subjek. Sumber karbohidrat yang biasa dikonsumsi oleh subjek antara lain nasi, jagung, kentang dan mie.

Sebanyak 79,6\% subjek memiliki asupan protein cukup. Asupan protein berhubungan dengan 
panjangnya fase folikuler. Asupan protein hewani yang berlebihan akan memperpanjang fase folikuler. Hal ini terbukti pada penelitian yang dilakukan untuk mengetahui pengaruh diet vegetarian terhadap hormon seks, 9 orang vegetarian diberikan diet yang mengandung daging mengalami pemanjangan fase folikuler rata-rata 4,2 hari, peningkatan $\mathrm{FSH}$, dan penurunan estradiol $\left(\mathrm{E}_{2}\right)$ secara signifikan. Sebaliknya 16 subjek dengan diet biasa yang beralih ke diet dengan rendah konsumsi daging selama dua bulan mengalami penurunan puncak $\mathrm{LH}$, peningkatan kadar LH dan pemendekan fase folikuler rata-rata 3,8 hari. ${ }^{4}$

Subjek dengan asupan protein kurang memiliki risiko 0,557 kali lebih besar untuk mengalami gangguan siklus menstruasi, meskipun secara statistik tidak ada hubungan asupan protein dengan siklus menstruasi $(p=0,322 ; \mathrm{RP}=0,557$; $95 \% \mathrm{CI}=0,207-1,500)$. Rerata asupan protein pada kelompok subjek dengan gangguan siklus menstruasi sebesar 52,2 $\pm 6,9$ gram dan pada kelompok subjek dengan siklus menstruasi normal sebesar 50,24 $\pm 11,5$ gram. Asupan protein pada kedua kelompok tergolong cukup. Berdasarkan hasil wawancara menggunakan kuesioner SQFFQ, sumber protein sebagian besar subjek merupakan makanan kaya fitoestrogen, seperti kedelai, tahu, tempe dan kacangkacangan.

Rata-rata asupan lemak pada kedua kelompok tergolong kurang, yaitu 48,8 $\pm 15,7$ gram pada subjek dengan gangguan siklus menstruasi dan $50,3 \pm 17,9$ gram pada subjek dengan siklus menstruasi normal. Diet rendah lemak akan menyebabkan tiga efek utama yaitu siklus menstruasi memanjang rata-rata 1,3 hari, lamanya waktu menstruasi meningkat rata-rata 0,5 hari dan fase folikuler meningkat rata-rata 0,9 hari. Wanita yang kekurangan asupan lemak, mengalami penurunan kadar hormon steroid. Semua hormon seks berasal dari hormon steroid yang diubah dari molekul kolesterol. Kolesterol sebagai prekursor steroid disimpan dalam jumlah banyak di sel-sel teka. Pematangan folikel yang mengakibatkan meningkatnya biosintesis steroid dalam folikel diatur oleh GnRH. Dibawah rangsangan LH, steroid diubah menjadi senyawa aktif secara androgenis oleh jaringan perifer yang mengakibatkan peningkatan kadar testosteron serum dan penurunan ekskresi 17 keto-steroid dalam urin sehingga berdampak pada perubahan siklus ovulasi dan terganggunya siklus menstruasi. ${ }^{7}$

Subjek dengan asupan lemak kurang memiliki risiko 0,973 kali lebih besar mengalami gangguan siklus menstruasi, meskipun secara statistik tidak ada hubungan asupan lemak dengan gangguan siklus menstruasi $\quad(p=1,000 ; \mathrm{RP}=0,973$;
95\% $\mathrm{CI}=0,505-1,874)$. Berdasarkan hasil wawancara menggunakan kuesioner SQFFQ, subjek lebih sering mengonsumsi makanan yang direbus atau ditumis daripada makanan yang digoreng.

Rata-rata asupan serat pada subjek yang mengalami gangguan siklus menstruasi lebih besar daripada pada subjek dengan siklus menstruasi normal, yaitu 20,4 \pm 7,6 pada subjek dengan gangguan siklus menstruasi dan 17,54 $\pm 8,3$ pada subjek dengan siklus menstruasi normal. Serat dapat membantu menurunkan produksi estrogen yang berlebihan dalam tubuh. ${ }^{21}$ Subjek dengan asupan serat kurang atau lebih memiliki risiko 0,815 kali lebih besar mengalami gangguan siklus menstruasi, meskipun secara statitistik tidak ada hubungan antara asupan serat dengan siklus menstruasi $(p=0,677 ; \mathrm{RP}=0,815 ; 95 \% \mathrm{CI}=0,461-1,439)$. Sebagian besar subjek mengonsumsi makanan sumber serat seperti bayam, brokoli, dan selada, dimana makanan tersebut juga mengandung fitoestrogen.

Keterbatasan penelitian ini karena besarnya variasi nilai asupan energi, karbohidrat, protein, lemak dan serat yang mungkin disebabkan oleh adanya bias pada saat pengambilan data asupan, yaitu keterbatasan responden dalam mengingat apa yang dikonsumsi, wawancara kurang mendalam, kesalahan menafsirkan ukuran rumah tangga (URT) dan adanya subjektifitas dari responden.

\section{Aktivitas Fisik dan Siklus Menstruasi}

Rata-rata aktivitas fisik kelompok subjek yang mengalami gangguan siklus menstruasi lebih besar, yaitu 536,6 \pm 517,8 MET-menit/minggu dan $454,5 \pm 411,0$ MET-menit/ minggu pada subjek dengan siklus menstruasi normal. Subjek dengan aktivitas fisik ringan memiliki risiko 0,877 kali lebih besar mengalami gangguan siklus menstruasi, meskipun secara statistik tidak ada hubungan antara aktivitas fisik dengan siklus menstruasi $(p=0,932 ; \mathrm{RP}=0,877 ; \quad 95 \% \mathrm{CI}=\quad 0,476-1,615)$. Aktivitas fisik berlebihan dapat menyebabkan terjadinya disfungsi hipotalamus yang menyebabkan gangguan pada sekresi GnRH. Hal tersebut menyebabkan menarche yang tertunda dan gangguan siklus menstruasi dengan perubahan metabolisme steroid yang memengaruhi pelepasan gonadotrophin. ${ }^{29}$

Ketidaksesuaian hasil penelitian dengan teori karena besarnya variasi nilai aktivitas fisik yang mungkin disebabkan oleh perbedaan aktivitas yang dilakukan responden serta adanya bias yaitu responden seringkali hanya mengingat kegiatan yang dilakukan tetapi tidak dapat memperkirakan jumlah waktu yang digunakan secara tepat. 


\section{Riwayat Gangguang Siklus Menstruasi pada Keluarga dan Siklus Menstruasi}

Sebanyak 91,7\% subjek yang memiliki riwayat gangguan siklus menstruasi pada keluarga mengalami gangguan siklus menstruasi pula. Hasil analisis bivariat menunjukkan bahwa terdapat hubungan antara riwayat keluarga dengan kejadian gangguan siklus menstruasi $(p<0,05 ; \mathrm{RP}=2,609 ; 95 \% \mathrm{CI}=1,631-4,174) . \quad$ Subjek dengan riwayat gangguan siklus menstruasi pada keluarga memiliki risiko 2,609 kali lebih besar untuk mengalami gangguan siklus menstruasi dibanding subjek yang tidak memiliki riwayat keluarga terkait kejadian gangguan siklus menstruasi.

Genetik merupakan salah satu faktor yang berperan pada siklus menstruasi. Kondisi anatomis dan fisiologis dari seseorang pada umumnya hampir sama dengan orang tua dan saudara-saudaranya. Riwayat keluarga memengaruhi keteraturan siklus menstruasi dan gangguan yang timbul saat menstruasi. Pada wanita yang memiliki riwayat gangguan siklus menstruasi pada keluarga akan berisiko lebih besar untuk mengalami gangguan menstruasi dibanding wanita yang tidak memiliki riwayat gangguan siklus menstruasi pada keluarga. ${ }^{23,32}$

\section{SIMPULAN}

Terdapat hubungan antara persentase lemak tubuh, konsumsi fitoestrogen dan riwayat gangguan menstruasi pada keluarga dengan siklus menstruasi $(p<0,05)$. Konsumsi fitoestrogen berhubungan dengan kejadian gangguan siklus menstruasi setelah dikontrol dengan persentase lemak tubuh dan riwayat gangguan menstruasi pada keluarga $(p<0,05)$.

\section{SARAN}

Wanita vegetarian dianjurkan untuk mengatur asupan zat gizi meliputi energi, karbohidrat, lemak, protein, serat dan fitoestrogen serta aktivitas fisik secara seimbang sehingga dapat mengurangi kejadian gangguan siklus menstruasi. Penelitian lebih lanjut tentang gangguan siklus menstruasi pada wanita vegetarian disarankan untuk dilakukan uji laboratorium terkait hormon yang memengaruhi siklus menstruasi.

\section{UCAPAN TERIMAKASIH}

Terimakasih kepada seluruh subjek dan pihak yeng telah berpartisipasi dalam penelitian ini.

\section{DAFTAR PUSTAKA}

1. Fraser GE. Vegetarian diets: what do we know of their effects on common chronic diseases? Am J Clin Nutr 2009; 89(suppl): 1607S-12S.
2. ADA Reports. Position of the American Dietetic Association: Vegetarian Diets. J Am Diet Assoc 2009; 109: 1266-1282.

3. Kusharisupeni. Vegetarian: Gaya Hidup Sehat Masa Kini. Yogyakarta: Andi, 2010.

4. Paath FE, Rumdasih Y, Heryati. Gizi dalam Kesehatan Reproduksi. Jakarta: EGC, 2004.

5. Gharravi AM. Menstrual Cycle Patterns of College Students in GorganNortheast of Iran: Identify Its Association with Sociodemographic Factors. Erciyes Med J 2009; 31(4): 331-338.

6. Nurlaila, Hazanah S, Shoufiah R. Hubungan Stress dengan Siklus Menstruasi pada Mahasiswa Usia 1821 Tahun. Husada Mahakam 2015; III No. 9: 452521.

7. Rakhmawati A, Dieny FF. Hubungan Obesitas dengan Kejadian Gangguan Siklus Menstruasi pada Wanita Dewasa Muda. J Nutr Coll 2013; 2: 214-222.

8. Tambing Y. Aktivitas Fisik dan Sindrom Premenstruasi pada Remaja. Universitas Gajah Mada, 2012.

9. Raharjo LH. Pengaruh Diet Vegan Terhadap Insiden Terjadinya Kanker Payudara. Biokimia Dep Lect Fac Med Univ Wijaya Kusuma Surabaya.

10. Khoswara S. Isoflavon, senyawa multi manfaat dalam kedelai. ebookpangan.com, 2006.

11. Patisaul HB, Jefferson W. The Pros and Cons of Phytoestrogens. Natl Institutes Heal 2010; 31(4): 400-419.

12. Burton JL, Wells M. The Effect of Phytoestrogens on the Female Genital Tract. J Clin Pathol 2002; 55: 401-407.

13. Arwini AE, Bahar B, Indriasari R. Hubungan Konsumsi Fitoestrogen dengan Siklus Menstruasi pada Siswi.

14. Wiknjosastro H. Ilmu Kandungan. Jakarta: Yayasan Bina Pustaka Sarwono Prawirohardjo, 2009.

15. Craig WJ. Health effects of vegan diets. Am J Clin Nutr 2009; 89(suppl): 1627S-33S.

16. Felicia, Hutagaol E, Kundre R. Hubungan Status Gizi dengan Siklus Menstruasi pada Remaja Putri di PSIK UNSRAT Manado. Keperawatan (e-Kp) 2015; 3: 17.

17. Brown JE, Isaacs JS, Krinke UB, et al. Nutrition Through the Life Cycle. 4th ed. Wadsworth Cengange Learning, 2011.

18. Rachmawati PA, Murbawani EA. Hubungan Asupan Zat Gizi, Aktivitas Fisik, dan Persentase Lemak Tubuh dengan Gangguan Siklus Menstruasi pada Penari. J Nutr Coll 2015; 4 Nomor 1: 39 - 49.

19. Lembaga Ilmu Pengetahuan Indonesia. Widyakarya Nasional Pangan dan Gizi. Jakarta, 2004.

20. Hughes. Phytoestrogen and Health. London: Food Standards Agency, 2003.

21. Gaskins AJ, Mumford SL, Wactawski-Wende J, et al. Effect of Daily Fiber Intake on Luteinizing Hormone Levels in Reproductive-Aged Women. Eur J Nutr 2012; 51: 249-253.

22. Ismail SI, Sulaiman N, Adnan R. Presents the proceedings 2nd International Colloquium on Sports Science, Exercise, Engineering and Technology 2015 
(ICoSSEET 2015). Springer Science+Business Media Singapore, 2016.

23. Novia I, Puspitasari N. Faktor Risiko yang Mempengaruhi Kejadian Dismenore Primer. Indones J Public Heal 2008; 4:2: 96-104.

24. Manuaba IAC, Manuaba IBGF, Manuaba IBG. Memahami Kesehatan Reproduksi Wanita. 2nd ed. Jakarta: Penerbit Buku Kedokteran EGC, 2006.

25. Wiknjosastro H, Saifuddin AB. Ilmu Kandungan. 2nd ed. Jakarta: Yayasan Bina Pustaka Sarwono Prawirohardjo, 2005.

26. Guyton AC, Hall JE. Buku Ajar Fisiologi Kedokteran. EGC 2008, 2008.

27. Sabbour A, El-Deeb A. Evaluation of Menstrual Status, Bone Mineral Density and Body Composition in Egyptian Ballet Dancers. Bull Fac Ph Th Cairo Univ 2011; 16:2: 61-69.

28. Halim AM, Bahar B, Indriasari R. Hubungan Konsumsi Fitoestrogen dengan Siklus Menstruasi pada Siswi di SMA Negeri 1 Tinggimoncong Kabupaten Gowa.

29. Asmarani R. Pengaruh Olahraga terhadap Siklus Haid Atlit. Universitas Diponegoro, 2010.

30. Marmi. Gizi dalam Kesehatan Reproduksi. Yogyakarta: Pustaka Pelajar, 2013.

31. Devi M. Hubungan Kebiasaan Makan dengan Kejadian Sindrom Pramenstruasi pada Remaja Putri. Teknol dan Kejuru 2009; 32 No.2: 197-208.

32. Saryono, Sejati W. Sindrom Premenstruasi. 1st ed. Yogyakarta: Nuha Medika, 2009. 